\title{
Total Factor Productivity, Demographic Traits and ICT: Empirical Analysis for Asia
}

\author{
Bilal MEHMOOD ${ }^{1}$, Parvez AZIM ${ }^{2}$ \\ ${ }^{1}$ Department of Economics, Government College University, Lahore, Pakistan \\ ${ }^{2}$ Department of Economics, Government College University, Faisalabad, Pakistan \\ digital.economist@gmail.com,dr_azim@hotmail.com
}

This paper advances a model to explain the total factor productivity in Asian countries, most of which are labor surplus and are endowed with substantial human capital. Such promising demographic potentials are considered as complementary factors to use of Information and Communication Technology (ICT). Population with such favorable demographic traits and access to ICT results in higher Total factor productivity (TFP). We call this as Demo-TechTFP Model and is tested by using data for 2000-2010 of 24 Asian countries. Econometric concerns like presence of endogenous and/or predetermined covariates and small time-series and cross-sectional dimensions of panel dataset are tackled by using System Generalized Method of Moments (SYS-GMM). Results show considerable support for the Demo-Tech-TFP hypothesis. Need is to design such models that suit the local demography and patterns of technological diffusion currently taking place in developing countries.

Keywords: Information and communication technology (ICT), Total Factor Productivity (TFP), Demographic features, Generalized Method of Moments

\section{1} Introduction

From pre-historic times man has undertaken to store, recollect, and process information as a source of value. Starting from image carving in stone walls to today's digital technology, the information is handled in a number of ways [24]. The ICT revolution is crucial insofar as it involves technologies geared to the production and dissemination of knowledge and information. These new technologies, that first emerged in the 1950s and then really took off with the advent of the Internet, have breath-taking potential [15]. ICT has affected agriculture, industry and services sectors of economies world over like no other technology in past [2]. Terms like information economy, digital economy, e-economy, weightless economy, paperless economy have been floated over the last 3 decades to term this readily evolving kind of economy. For instance, one of the pioneering works in this regard was a report by [35]. Later, during mid-90s term 'New Economy' was introduced to represent the marvelous growth in software industry in US.

In his famous treatise, 'Major Economic Cycles', [30] has pointed out the existence of tides of surging economic activity. These economic cycles are called as 'Kondratiev Waves'. There is growing consensus that the rise of 'New economy' during 1990s and the burst of the 'dotcom' bubble in 2001 can be the $5^{\text {th }}$ Kondratiev Wave and the stimulus behind it is ICT [30].

\section{ICT in Asian Region}

Asia as one of the densely populated regions of the world has shown high demand for ICT products after the falling prices of ICT equipment during the last quarter of $20^{\text {th }}$ century. Policy reforms of deregulation and privatization in Asian countries like India, Pakistan, China and Indonesia and has enabled the spread of ICT [39].

A dataset of 24 countries is included in empirical analysis for the time span 2000-2010 depending on the availability of data. The chosen indicators are fixed broadband internet subscribers (FBBS), fixed internet subscribers per 100 inhabitants (FIS), internet users per 100 inhabitants (INTU), fixed telephone lines per 100 inhabitants (FTL), information \& communication technology maturation index (ICTMI), internet users per 100 inhabitants (INTU) and mobile cellular telephone subscriptions per 100 inhabitants 
(MBLC). ICTMI (Information and Communication Technology Maturation Index) is inspired from Information and Communication Development Index (IDI) in [42] 'Measuring Information Society' published by International Telecommunication Union (ITU).

\section{Literature Survey}

Studies at macroeconomics level showing the impact of demographic factors and ICT on TFP are, to our knowledge, scarce. [20] explore the ICT-productivity relationship in Spanish firms. Their innovation was to introduce a set of organizational variables (workers' qualifications, management attitude and process innovation) which would support the ICT to have its impact on organizational productivity. Their findings affirm the role of (organizational) complementary factors in strengthening the ICT-productivity relationship.

A handful of studies conducted for Asian region disclosed the need for e-skills, ereadiness and e-competence of human resource. Traits like attitude towards and believes about ICT are also researched. These studies have tried to explain the ICTproductivity nexus using this human capital related framework [5] and [17]. But for Asian region, the demographic factors along with ICT have not been incorporated in the empirical analysis. Other explanations have also been given for the fuzziness of ICTproductivity relationship. For example, [4] argues that lags between implementation of ICT and their effect on productivity.

In effort of spiraling down to main debate, this study suggests a newer set of complementary factors including demographic factors and welfare related factors. In this study, complementary factors are divided into two major categories and are explained below:

\section{Demographic Features}

From demographic point of view, a few factors are listed and explained in the light of existing empirical literature.

\subsection{Economically Productive Youth}

Youth, here, refers to age group that is capa- ble of contributing to production in an economy. The salient trait of Asian region (especially the developing countries) is the young population which implies potential human resource as revealed by population pyramids and their forecasts. Asian Miracle is considered an outcome of the young population in East Asian countries [9]. Such population combined with ICT can increase productivity. Younger people adopt the internet more as compared to older people [22]. [1] also found similar results for youth.

In relatively advanced countries like those in Europe young population that uses the advanced ICT for recreational and economically productive purposes is termed as digital natives' [18]. Age and gender are previous related with ICT by [34]. Authors examine the patterns of IT in five countries, considering the deviations in IT usage across gender, education, age and income groups. This study hypothesizes a certain age cohort to be relatively more productive that is termed as 'digitally productive' group of population.

\subsection{Urban Population}

[19] inquire the difference between access to ICT in rural and urban areas of Tanzania and find no significant difference. This opens the debate for inquiring the impact of urban-rural population in a country in relation with ICT adoption. Under the theory of agglomeration economies, greater urban area and population is considered to be an advantage to a country. Therefore, the population/labor in urban areas is relatively more productive than population in non-urban areas. Increased usage of ICT by such 'more productive' population can become a cause of increased productivity.

\subsection{Welfare Related Factor: Human De- velopment Index}

A population with higher HDI (higher education, better health and good standard of living) is hypothesized to be more productive user of ICT. Empirical literature in this direction is very limited. [32] finds similar results for West African countries. While [1] in their exploratory study find that countries with 
low HDI rank have citizens who are less connected.

\section{Hypothesis}

For inquiring ICT-productivity nexus with complementary factors (henceforth Demo-
Tech-TFP Model), following hypothesis is developed:

$\mathbf{H}_{\mathrm{A}}$ : ICT will contribute more to TFP when coalesced with complementary factors (favorable demographic features and greater human development).

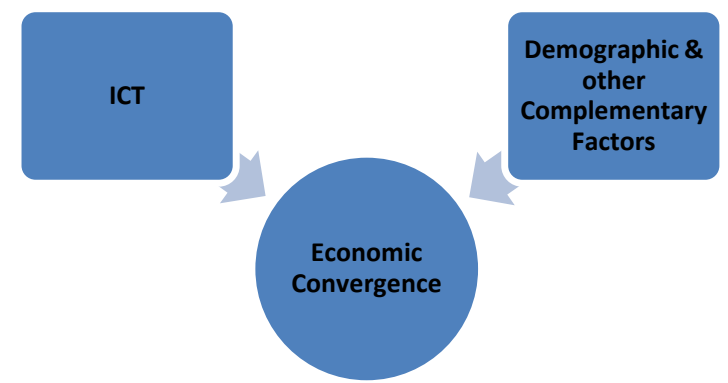

Fig. 1. Converging Radial Diagram for ICT Augmented Convergence Hypothesis Source: Inspired from Barro and Sala-i-Martin (1992)

\subsection{Sample Issues and Data Sources}

A dataset of mixed sample of countries of Asian region (few DCs and mostly UDCs) is gleaned depending on availability of data for relevant variables. A maximum of 24 countries are selected while the number of years is 11. $\mathrm{T}=11$ and $\mathrm{N}=24$ and $\mathrm{t}<\mathrm{n}$. Collection of data is done from World Development Indicators (WDI) and International Telecommunication Union (ITU) for selected Asian countries.

\section{Development of Demo-Tech-TFP Hy- pothesis}

The model developed in this study is named as Demo-Tech-TFP Model. Based on the factors included in it i.e. demographic features and information and communication technology, the term Demo-Tech-TFP Model is devised. Emphasis is kept on demographic factors and ICT, since they are likely to have strong complementarities. Among other variable is human development index. Human Development Index is expected to have a significant influence on the ability of the ICT users to be more productive and capable of contributing to TFP.

\section{Estimable Model}

Demo-Tech-TFP model is estimated for assessing the role of ICT, along with complementary factors, in explaining TFP:
TFP $_{i, t}=\varphi\left(\right.$ ICTMI $_{i, t}, \quad$ ICTSERT $_{i, t}, \quad$ p1564 $_{i, t}$, $\left.\operatorname{URBNP}_{\mathrm{i}, \mathrm{t}}, \mathbf{H D I}_{\mathrm{i}, \mathrm{t}}\right) \ldots \ldots \ldots \ldots \ldots \ldots \ldots \ldots$ .......(1)

$\mathbf{T F P}_{i, t}=\alpha_{i}+\alpha_{i, t}^{\prime}\left(\mathbf{T F P}_{\mathbf{i}, \mathbf{t}-1}\right)+\beta_{\mathrm{i}, \mathrm{t}}\left(\mathbf{I C T M I}_{\mathrm{i}, \mathrm{t}}\right)+\gamma_{\mathrm{i}, \mathrm{t}}$ $\left(\right.$ ICTSERT $\left._{\mathrm{i}, \mathrm{t}}\right)+\delta_{\mathrm{i}, \mathrm{t}}\left(\mathbf{p 1 5 6 4}_{\mathrm{i}, \mathrm{t}}\right)+\kappa_{\mathrm{i}, \mathrm{t}}\left(\right.$ URBNP $\left._{\mathrm{i}, \mathrm{t}}\right)+\lambda_{\mathrm{i}, \mathrm{t}}$ $\left(\mathbf{H D I}_{\mathrm{i}, \mathrm{t}}\right)+\Omega\left(\mathbf{T}_{\mathrm{t}}\right)+\varepsilon_{\mathrm{i}, \mathrm{t}} \ldots \ldots \ldots \ldots \ldots \ldots \ldots \ldots$ (1e)

Here, TFP is total factor productivity calculated as the contribution of all other factor to national income in addition to labor and capital. $\mathbf{T}_{\mathbf{t}}$ is vector of time dummies, $\Omega$ their respective coefficients and $\boldsymbol{\varepsilon}_{\mathbf{i}, \mathbf{t}}$ is the error term. i shows countries and $\mathbf{t}$ years. Arithmetically speaking:

$\mathbf{T F P}_{\mathrm{i}, \mathrm{t}}=\mathbf{Y C D}_{\mathrm{i}, \mathrm{t}}-\widehat{\alpha} \cdot \mathbf{L}_{\mathrm{i}, \mathrm{t}}-(1-\widehat{\alpha}) \mathbf{K}_{\mathrm{i}, \mathrm{t}} \ldots \ldots \ldots(1-$ A)

For an overall representation of ICT Information \& Communication Technology Maturation Index (ICTMI) is used. ICT goods imports as \% total goods imports (ICTM) is used as an 'external instrument' as suggested in [38]. For the complementary effects, ICTSERT is calculated as the product of ICT and SERT. Following [6] 'tertiary school enrollment (\% gross)' (SERT) is used as a proxy of human capital. In lieu of 'secondary school enrolment' (SERS), SERT is preferred cause people with higher levels of education enrolment are more intensive and economically productive users of ICT. SERT is also justified as higher levels of education invites greater 'ICT diffusion' in the economy and augments ICT-productivity nexus [13]. 
For the complementary effects arising from demographic features of sample countries, p1564 (population with at between 15 and 64 years) and URBNP (\%age of urban population) are included. Welfare related complementarity is investigated using HDI (Human Development Index).

\subsection{Probing for Endogeneity - Durbin- Wu-Hausman Tests}

Since endogeneity is expected in the estimable model, the Durban-Wu-Hausman tests for endogeneity in IV regressions is employed as follows:

\begin{tabular}{|c|c|c|c|}
\hline \multicolumn{4}{|c|}{ Null Hypothesis $\left(\mathbf{H}_{\mathbf{0}}\right)$ : Regressor is Exogenous } \\
\hline Test & Notation & Statistic & p-value \\
\hline Wu-Hausman F test & $\mathrm{F}(1,208)$ & 40.000 & 0.000 \\
\hline Durbin-Wu-Hausman $\chi^{2}$ test & $\chi^{2}(1)$ & 41.530 & 0.000 \\
\hline
\end{tabular}

\subsection{Decision on Using IV Regression or GMM - IV-Heteroskedasticity Tests}

As per [7], GMM gives more efficient estimates as compared to simple Instrumental Variables (IV) Regression when heteroskedasticity exists. In presence of

heteroskedasticity, GMM estimator is a better estimator. These tests are as follows:

\begin{tabular}{ccc}
\hline \hline Table 3. IV-Heteroskedasticity Tests Using Levels Of IVs \\
\hline \hline \multicolumn{2}{c}{ Null Hypothesis $\left(\mathbf{H}_{\mathbf{0}}\right)$ : Disturbance is Homoskedastic } \\
\hline \hline Test & $\chi^{\mathbf{2}}(\mathbf{6})$ & p-val \\
\hline Pagan-Hall General Test Statistic & 14.662 & 0.023 \\
\hline Pagan-Hall Test w/assumed Normality & 49.101 & 0.000 \\
\hline White/Koenker $n R_{c}^{2}$ Test Statistic & 16.050 & 0.014 \\
\hline Breusch-Pagan/Godfrey/Cook-Weisberg & 53.426 & 0.000 \\
\hline \hline
\end{tabular}

Results of the two tests are in favor of presence of heteroskedasticity. BreuschPagan/Godfrey/Cook-Weisberg and White/Koenker $n R_{c}^{2}$ test statistics are statistically significant at $1 \%$ level of significance. Pagan-Hall General test and Pagan-Hall Test w/assumed Normality statistics show reveal homoskedasticity. Since half of tests reveal the presence of heteroskedasticity, it is safer to assume heteroskedasticity and GMM should be preferred.

ICTMI, ICTM is used as an 'external instrument' as suggested in [38]

\subsection{System GMM Results.}

\section{Table 5: SYSTEM GMM Estimates (Impact of Demographic Complementary Factors and ICT on Total} Factor Productivity)

\begin{tabular}{|c|c|c|c|c|}
\hline \multicolumn{5}{|c|}{ Dependent Variable: Total Factor Productivity $\left(\mathbf{T F P}_{\mathrm{i}, \mathrm{t}}\right)$} \\
\hline & Coefficients & Standard Errors & t-statistics & p-values \\
\hline TFP $_{\mathrm{i}, \mathrm{t}-1}$ & 0.9394 & 0.0713 & 13.17 & 0.000 \\
\hline ICTMI $_{\mathrm{i}, \mathrm{t}}$ & 0.0156 & 0.0063 & 2.48 & 0.014 \\
\hline ICTSERT $_{\mathrm{i}, \mathrm{t}}$ & 0.0182 & 0.0037 & 4.86 & 0.000 \\
\hline $\mathbf{P 1 5 6 4}_{\mathrm{i}, \mathrm{t}}$ & 0.0135 & 0.0102 & 1.33 & 0.186 \\
\hline URBNP $_{\mathrm{i}, \mathrm{t}}$ & 0.0713 & 0.0270 & 2.64 & 0.009 \\
\hline HDI $_{\mathbf{i}, \mathbf{t}}$ & 0.0117 & 0.0516 & 0.23 & 0.821 \\
\hline $\mathbf{C}$ & -0.3387 & 0.3382 & -1.00 & 0.318 \\
\hline \multicolumn{5}{|c|}{ Time Dummies } \\
\hline yrtd_02 & -0.0329 & 0.0129 & -2.56 & 0.011 \\
\hline yrtd_03 & -0.0289 & 0.0130 & -2.22 & 0.027 \\
\hline yrtd_04 & -0.0303 & 0.0127 & -2.39 & 0.018 \\
\hline yrtd_05 & -0.0306 & 0.0135 & -2.27 & 0.024 \\
\hline yrtd_06 & -0.0266 & 0.0103 & -2.57 & 0.011 \\
\hline yrtd_07 & -0.0305 & 0.0103 & -2.97 & 0.003 \\
\hline yrtd_08 & -0.0176 & 0.0079 & -2.24 & 0.026 \\
\hline yrtd_09 & 0.0012 & 0.0021 & 0.50 & 0.615 \\
\hline \multicolumn{5}{|c|}{ Other Tests and Parameters } \\
\hline Observations $=216$ & Countries $=24$ & Instruments $=29$ & $\mathbf{F}(\mathbf{1 4}, \mathbf{2 3})=621$ & $=0.000]$ \\
\hline \multicolumn{2}{|c|}{ p-value: Hansen J-Test $=0.935$} & \multicolumn{3}{|c|}{$\mathbf{M}_{1}: p=0.077 \& \mathbf{M}_{2}: p=0.185$} \\
\hline \multicolumn{5}{|c|}{ Difference in Hansen tests / C-tests: $[\mathrm{p}=0.658, \mathrm{p}=0.961, \mathrm{p}=0.822 \& \mathrm{p}=0.935]$} \\
\hline
\end{tabular}


Note: Following Roodman (2006) and Mileva (2007), SGMM is applied on model with arguments small, twostep and robust.

\section{Interpretation}

The total factor productivity model estimations reveal the existence of relationship between ICT and TFP hinged upon the demographic complementary factors. Lagged value of total factor productivity is positively related with its previous values, revealing the dynamic behavior of the variable. Hence gives rise to a dynamic panel model. Its statistical significance is at all levels. The main variable of interest is ICTMI that has a positive influence on TFP (total factor productivity) as depicted by its positive sign of regression coefficient that is statistically significant. ICTSERT (ICT $\times$ SERT) is also used in the regression which captures the interaction of ICT and school enrolment rate at tertiary level. This coefficient also has a significant and positive influence on TFP. This implies that ICT has complementarity with tertiary level of education. In simpler terms, highly educated users (labor) of ICT are economically more productive labor. Statistical significance of this regressor is only at $10 \%$.

The proxy for economically active youth, population aged between 15-64 years is also included. The meaning of young population here is in terms of their contemporariness to ICT and physical and mental fitness to adopt and use ICT. It shows a positive relationship with total factor productivity. It is institutive as young labor force is more ICT-savvy. 'ICT-savvy' means proficient user of information and communication technology. Statistically significant is absent for this variable.

Another fragment of population that is likely to be relatively more productive is the urban population. Population in urban areas gets better education and job opportunities due to urbanization economies. Urbanization economies contain benefits like proximity of markets, skilled and more educated labor, financial services, better information and communication facilities and knowledge spillovers. Considering these facts, this demo-tech-TFP regression includes urban population (URBNP) as demographic factor.
This regressor is showing positive influence on total factor productivity and supporting the argument of urbanization economies. Its statistical significance is at $1 \%$ level of significance. In an economic jargon, this coefficient indicates towards 'ICT-augmented agglomeration economies' in large urban areas. This term is devised from the standard term of agglomeration economies.

Human welfare can also contribute to total factor productivity. Accordingly, HDI is included as a determinant of TFP. Its role turns out to be positive and statistically significant. The result for this regressor is quite intuitive. Its positive role is justified on the basis of its three tiered role i.e. health (life expectancy), educational inclination and economic performance of country. All three components of HDI, in presence of ICT, contribute better towards TFP. In another connotation, labor with higher welfare and ICT is likely to be more productive.

In addition to regressors, time dummies as also estimated to overcome the problem of cross-sectional dependence and to cope with universal time-related shocks from $\boldsymbol{\varepsilon}_{\mathbf{i}, \mathbf{t}}$ [40].

Overall significance of the model is agreeable at $1 \%$ level of significance as revealed by F-test of joint significance. The condition that number of observations is greater than number of instruments holds in this case i.e. $(240>29)$. Hansen test of correct specification and over-identifying restrictions has a pvalue of greater than 0.05 . i.e. ( $p$-value $=$ $0.935>0.05$ ) implying that all overidentified instruments are exogenous. The Arellano \& Bond test for first order ' $\mathrm{M}_{1}$ ' and second order ' $\mathrm{M}_{2}$ ' correlation i.e. $\mathrm{AR}(1)$ and $\mathrm{AR}(2)$ show $\mathrm{p}$-value of greater than 0.000 . i.e. $\left(\mathrm{M}_{1}\right)_{\text {p-value }}=0.077>0.05$ and $\left(\mathrm{M}_{2}\right)_{\mathrm{p} \text {-value }}=$ $0.185>0.05$. Hence there is no second order serial correlation in residuals.

C-test developed by [8] and [37] for the validity of subsets of instruments for level and difference equations are also satisfactory. These tests are four in number and have same criteria, i.e. the p-value should be greater than 0.05: 
$(\mathrm{C} \text {-test })_{\text {Ho: GMM-differenced instruments are exogenous }}=$ $0.658>0.05$

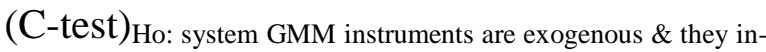
crease Hansen J-test $=0.961>0.05$

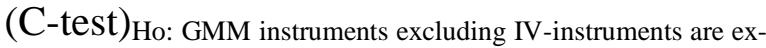
ogenous $=0.222>0.05$

$(\mathrm{C} \text {-test })_{\text {Ho: }}$ Standard IV-instruments are exogenous \& they increase Hansen J-test $=0.935>0.05$

There is not enough evidence to reject the null hypotheses set in these four tests of difference-in-Hansen/C-tests.

\section{Conclusion}

From empirical results, it is deduced that demographic and welfare related factors complement the ICT-TFP relationship. The expectation that ICT alone may not ameliorate TFP is affirmed by our analysis. Complementary factor such as population in large urban areas is found to enhance the ICT-TFP relationship. Such digitally literate population is found to be economically more productive. Similar implications are found for age cohort of population that is economically active. More specifically, it is affirmed that populations with higher level of HDI (education, health and living standards) are better able to use ICT for productive purposes contributing to national income. The innovative model developed in this study explains TFP from the point of view of ICT, demography and welfare levels.

\subsection{Recommendations}

Findings in this study related to HDI shows that merely throwing ICT at the disadvantaged populations/regions shall not bring the desired result of increased productivity. For that the funding agencies have to embed these ICT development programs with awareness campaigns so as to enable the target population for the economically productive usage of ICT equipment. For instance program of ICT4D (Information and Communication Technology for Development) faces issue of poor infrastructure, low illiteracy and poor health in implementing the ICT-based development projects in disadvantaged regions like Africa. For more see Heeks (2002). As highlighted in the empirical anal- ysis of this study youth, combined with ICT diffusion, can contribute to level of productivity. Most of sample countries, have shown greater proportion of youth in total population. Need is to channelize this youth but making them digitally literate so they contribute to national income. In brief this finding of the study suggests a form of manpower planning which focuses the ICT skills to channelize the benefits of favorable demographic features.

\section{References}

[1] B. M. Abdelfattah, K. Bagchi, G. Udo, and P. Kirs, "Understanding the Internet Digital Divide: An Exploratory Multi-Nation Individual-Level Analysis", AMCIS 2010 Proceedings. Paper 542. Retrieved http://aisel.aisnet.org/amcis2010/542

[2] T. J. Allen, and M.S. Morton, Information Technology and the Corporation of the 1990s: Research studies. Oxford University Press, 1995.

[3] M. Arellano, and S. Bond, "Some Tests of Specification for Panel Data: Monte Carlo Evidence and an Application to Employment Equations". The Review of Economic Studies, Vol. 58(2), 1991, pp. 277-297.

[4] C. Avgerou, "How Can IT Enable Economic Growth in Developing Countries?", Information Technology for Development, Vol. 8(1), 1998, pp. 15-28.

[5] H. Awang, "Human Capital and Technology Development in Malaysia", International Education Journal, Vol. 5(2), 2004, pp. 239-246.

[6] R. Barro, and J.W. Lee, "Sources of Economic Gowth", Carnegie Rochester Conference Series on Public Policy, Vol. 40(384), 1994, pp. 1-46.

[7] C.F. Baum, M.E. Schaffer, and S. Stillman, "Instrumental Variables and GMM: Estimation and Testing", Stata Journal, Vol. 3(1), 2003, pp. 1-31.

[8] C.F. Baum, An Introduction to Modern Econometrics using Stata: Stata Corp, 2006. 
[9] D.E. Bloom, and J.G. Williamson, "Demographic Transitions and Economic Miracles in Emerging Asia", The World Bank Economic Review, Vol. 12(3), 1998, pp. 419-455.

[10] R. Blundell, and S. Bond, "Initial Conditions and Moment Restrictions in Dynamic Panel Data Models", Journal of Econometrics, Vol. 87(1), 1998, pp. 115143.

[11] S. R. Bond, "Dynamic Panel Data Models: A Guide to Micro Data Methods and Practice", Portuguese Economic Journal, Vol. 1(2), 2002, pp. 141-162.

[12] T.S. Breusch, and A.R. Pagan, "A Simple Test for Heteroskedasticity and Random Coefficient Variation", Econometrica, Vol. 47, 1979, pp. 12871294.

[13] G. Cette and J. Lopez, "What Explains the ICT Diffusion Gap Between the Major Industrialized Countries: An Empirical Analysis?", International Productivity Monitor, Vol. 17, 2008, 28-39.

[14] R.D. Cook and S. Weisberg, "Diagnostics for Heteroscedasticity in Regression", Biometrika, Vol. 70, 1983, pp. 1-10.

[15] P.F. Drucker, "The World According to Peter Drucker Take-Aways", Free Press, 1998.

[16] S. Dutta and A. Jain, "The Network Readiness Index 2003-2004", The Global Information Technology Report 20032004. Geneva: World Economic Forum.

[17] M.A. Elsadig, "ICT and Human Capital Role in Achieving Knowledge-Based Economy: Applications on Malaysia's Manufacturing", Journal of Information and Knowledge Management, Vol. 5(2), 2006, pp. 117-128.

[18] European Commission (2010). Europe's Digital Competitiveness Report, Commission Staff Working Document. Vol. I.

[19] B. Furuholt and S. Kristiansen, "A Rural-Urban Digital Divide? Regional Aspects of Internet Use in Tanzania", EJISDC, Vol. 31(6), 2007, pp. 1-15.

[20] A. Gargallo-Castel C. Galve-Gorriz, "Information Technology, Complementa- rities and Three Measures of Organizational Performance: Empirical Evidence from Spain", Journal of Information Technology Impact, Vol. 7(1), 2007, pp. 43-58.

[21] L.G. Godfrey, "Testing for Multiplicative Heteroskedasticity", Journal of Econometrics, Vol. 8, 1978, pp. 227-236.

[22] A. Goldfarb and J. Prince, "Internet Adoption and Usage Patterns are Different: Implications for the Digital Divide". Information Economics and Policy, Vol. 20(1), 2008, pp. 2-15.

[23] R. Heeks, “i-development not edevelopment: Special Issue on ICTs and Development", Journal of International Development, Vol. 14(1), 2002, pp. 1-11.

[24] G.D. Hutcheson, "The Economic Implications of Moore's Law. In H. R. Huff (Ed.)", Into the Nano Era (pp. 11-38), 2009, Berlin Heidelberg: Springer.

[25] IDC (2007). Information Society Index, International Data Corporation (IDC), Retrieved from: http://www.idc.com/getdoc.jsp?containerI $\mathrm{d}=204122$

[26] ITU. (2003). World Telecommunications Development Report 2003: Access Indicators for the Information Society. Geneva: ITU. Retrieved from www.itu.int/ITU-

D/ict/publications/wtdr_03/index.htm.

[27] ITU. (2005). Measuring Digital Opportunity. Geneva: ITU. Retrieved from http://www.itu.int/ituwsis/2005/DOI\%20V2.pdf.

[28] J.Y. Jung, J.L. Qiu and Y.C. Kim, "Internet Connectedness and Inequality: Beyond the Divide.", Communication Research, Vol. 28(4), 2001, pp. 507-535.

[29] R. Koenker, "A Note on Studentizing a Test for Heteroskedasticity", Journal of Econometrics, Vol. 17, 1981, pp. 107-112.

[30] A.V. Korotayev and S.V. Tsirel, "A Spectral Analysis of World GDP Dynamics: Kondratieff Waves, Kuznets Swings, Juglar and Kitchin Cycles in Global Economic Development, and the 2008-2009 Economic Crisis", Structure and Dynamics, Vol. 4(1), 2010, Retrieved from: 
http://www.escholarship.org/uc/item/9jv1 $08 \times p$

[31] E. Mileva, "Using Arellano-Bond Dynamic Panel GMM Estimators in Stata", Economics Department, Fordham University, New York, 2007. Retrieved from: http://www.fordham.edu/ economics/mcleod/Elitz-

UsingArellano\%E2\%80\%93BondGMME stimators.pdf

[32] O. Ngwenyama, F.K. Andoh-Baidoo, F. Bollou and O. Morawczynski, "Is There a Relationship Between ICT, Health, Education and Development? An Empirical Analysis of Five West African Countries from 1997-2003", The Electronic Journal on Information Systems in Developing Countries, Vol. 23(5), 2006, pp. 1-11.

[33] J. Nurmela and M. Viherä, "Communication Capability is an Intrinsic Determinant for the Information Society", $\mathrm{Fu}$ tures, Vol. 3, 2000, pp. 245-65.

[34] H. Ono and M. Zavodny, "Digital Inequality: A Five Country Comparison Using Microdata", Social Science Research, Vol. 36(3), 2007, pp. 1135-1155.

[35] M.U. Porat, "Information Economy". Technology, 2010 (1/12/2010), 1-18. Harvard Business School Press. Retrieved from

http://www.oecd.org/department/0,3355,e n_2649_33757_1_1_1_1_1,00.html

[36] C.A. Primo Braga, C. Fink and C.P. Sepulveda, "Intellectual Property Rights and Economic Development", 2000, World Bank Discussion Papers.

[37] D. Roodman, How to Do xtabond2: An Introduction to "Difference" and "System" GMM in Stata, Working Papers 103, 2006, Center for Global Development.
[38] D. Roodman, "A Note on the Theme of Too Many Instruments", Oxford Bulletin of Economics of Statistics, Vol. 71(1), 2009, pp. 135-158.

[39] R. Samarajiva and A. Zainudeen, ICT Infrastructure in Emerging Asia: Policy and Regulatory Roadblock. 2008, India: Sage Publications.

[40] V. Sarafidis, T. Yamagata and R. Robertson, "A Test of Cross-Section Dependence for a Linear Dynamic Panel Model with Regressors", Faculty of Economics, University of Cambridge, 2006, available on line at: http://www.econ.cam.ac.uk/faculty/roberts on/HCSDtest14Feb06.pdf.

[41] L.D. Stanley, "Beyond Access: Psychosocial Barriers to Computer Literacy". The Information Society, Vol. 19, 2003, pp. 407-416.

[42] S. Teltscher, E. Magpantay, V. Gray, D. Olaya and I. Vallejo, Measuring the Information Society: The ICT Development Index: Telecommunication Development Bureau, International Telecommunications Union (ITU): Geneva, 2010, accessed at http://www. itu. int/net/pressoffice/backgrounders/general/ pdf/5.pdf

[43] S. Welling and H. Kubicek, Measuring and Bridging the Digital Divide in Germany. Report presented at the International Conference, Stepping-Stones into the Digital World, September, Bremen, 2010. Retrieved from http://www.digitalechancen.de/transfer/downloads/MD35.pdf

[44] H. White, A HeteroskedasticityConsistent Covariance Matrix Estimator and a Direct Test for Heteroskedasticity. Econometrica, Vol. 48, 1980, pp. 817-838.

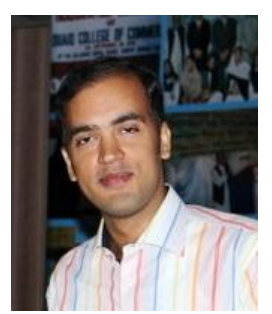

Bilal MEHMOOD has graduated the Master in Economics in 2003. He obtained an MPhil degree in 2006 in Economics from GC University, Lahore, Pakistan. His is from PhD degree from GC University, Faisalabad. He also holds Diploma in Information Technology from Punjab Information Technology Board, Pakistan. He is an awarded of The Gold Standard of International Award for Young People, The Duke of Edinburgh Award. He is a participant of International Growth Centre (IGC) Pakistan, a policy consortium set up by the London School of Economics (LSE) and Oxford University. Currently, he is serving GC 
University, Lahore, Pakistan as a senior lecturer in Department of Economics. He has conducted and edited Survey projects with Punjab Small Industries Corporation under Government of The Punjab, Pakistan. He is the author of more than 30 articles and two books in the fields of ICT economics and knowledge economy, among others. His work is currently in Romanian Review of Social Sciences (RRSS) and is forthcoming in Oeconomics of Knowledge and Romanian Economic Journal (REJ). His work concentrates on the role of ICT and knowledge in development of UDCs.

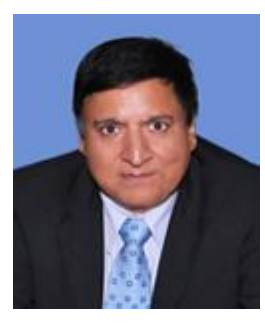

Parvez AZIM is Foreign Faculty Professor of Economics and a $\mathrm{PhD}$ in Economics from Taxas A\&M University, USA. He is not only a known figure in the field of economics but also in the field of mathematical economics. His articles and books are well recognized in the comity of economic scientists. He is currently supervising $\mathrm{PhD}$ and MPhil theses. Previously he has served at Quaid-e-Azam University Islamabad, Govt. College University Lahore, University of Gujrat, University of Sargodha, in the Ministry of Education Brunei Dar-us-Salam and on number of national and international projects. He is a member of editorial board of International Journal of Pluralism and Economics Education USA. 